\title{
Relationship between the severity of mitral regurgitation, left ventricular dysfunction and plasma brain natriuretic peptide level: An observational strain imaging study
}

\author{
Mitral yetersizliği şiddeti, sol ventrikül fonksiyon bozukluğu ve plazma beyin natriüretik peptit \\ düzeyi arasındaki ilişki: Bir gözlemsel strain görüntüleme çalışması
}

\author{
Mehmet Ali Elbey ${ }^{1}$, Şakir Arslan², Enbiya Aksakal' ${ }^{2}$, Hüseyin Şenocak ${ }^{2}$, Şule Karakelleoğlư ${ }^{2}$, Zuhal Arıtürk ${ }^{1}$, \\ Ebru Öntürk Tekbaşs ${ }^{1}$, Habib Çil ${ }^{1}$
}

\begin{abstract}
Objectives: The aim of the this study was to investigate the relationship between the degree of mitral regurgitation (MR), left ventricular (LV) dysfunction determined by strain (S)/strain rate (SR) imaging and plasma brain natriuretic peptide (BNP) levels.
\end{abstract}

Materials and methods: This is an observational crosssectional study which included 31 consecutive patients (15[48.4\%] male) who had applied to our outpatient clinics and diagnosed as mitral regurgitation and 25 (12 [48.0\%] male) healthy persons as control subjects. The mitral regurgitation patients were divided into two groups: those with moderate MR $(n=14[45.2 \%])$ and those with severe MR ( $n=17[54.8 \%])$, and maximum strain / strain rate measurements of left ventricular wall segments and plasma brain natriuretic peptide levels were determined in these two groups and controls.

Results: S/SR values of all wall segments of left ventricle were found to be decreased in patient with severe MR when compared with the control subjects and patients with moderate MR $(p<0.001)$.

Conclusions: Although left ventricle functions with conventional echocardiography in patients with mitral valve regurgitation were normal, subclinic deteriorations of left ventricle were detected in patients with severe mitral valve regurgitation. J Clin Exp Invest 2012; 3 (4): 451-456

Key words: strain/strain rate, echocardiography, mitral regurgitation, left ventricular functions

\section{ÖZET}

Amaç: Bu çalışmada mitral yetersizliği ve strain/strain rate $(S / S R)$ ekokardiyografi ile tespit edilen sol ventrikül disfonksiyonunun derecesi ile plazma beyin natriüretik peptid seviyesi arasındaki ilişkinin araştırılması amaçlanmıştır.

Gereç ve yöntem: Mevcut çalışma kesitsel, gözlemsel bir çalışmadır. Bu çalışmaya polikliniğimize başvurmuş olan ardışık 31 mitral yetersizliği hastası (15’i [\%48,4] erkek) ve kontrol grubu olarak 25 sağlıklı birey $(12$ 'si [\%48,0] erkek) alınmıştır. Hastalar orta derecede mitral yetmezliği olanlar $(n=14[\% 45,2]$ ve ileri derecede mitral yetmezliği olanlar $(n=17[\% 54,8]$ olarak iki gruba ayrılmışlar ve üç grupta sol ventrikül duvar segmentlerinin maksimum strain / strain rate ölçümleri kaydedilmiş, plazma beyin natriüretik peptit seviyeleri ölçülmüştür.

Bulgular: İleri MY olan hastalarda orta MY ve kontrol grubu ile karşılaştıııldığında ileri MY grubunda sol ventrikül segment S/SR değerlerinde daha belirgin azalma izlendi $(p<0,001)$.

Sonuç: MY olan hastaların her ne kadar konvansiyonel ekokardiyografik olarak sol ventrikül fonksiyonları normal olmasına rağmen ileri MY olan grubun sol ventrikül fonksiyonlarında subklinik bozulma izlendi.

Anahtar kelimeler: Strain/strain rate, ekokardiyografi, mitral yetersizliği, sol ventrikül fonksiyonları

${ }^{1}$ Dicle University Faculty of Medicine, Department of Cardiology, Diyarbakır, Turkey

${ }^{2}$ Atatürk University Faculty of Medicine, Department of Cardiology, Erzurum, Turkey

Correspondence: Mehmet Ali Elbey,

Dicle University Faculty of Medicine, Department of Cardiology, Diyarbakır, Turkey Email: elbeymali@hotmail.com

Received: 30.09.2012, Accepted: 30.10.2012

Copyright (C) JCEI / Journal of Clinical and Experimental Investigations 2012, All rights reserved 


\section{INTRODUCTION}

Mitral regurgitation (MR) is common and the severity of regurgitation tends to increase with age. ${ }^{1}$ Due to adaptive remodeling of the left ventricle (LV) and left atrium (LA), patients can remain asymptomatic or minimally symptomatic for prolonged periods, even in the presence of severe MR. However, MR goes with a progressive remodeling of LV, leading eventually to the development of LV dysfunction, which may be irreversible. ${ }^{2}$ However, the difficulties in detecting early LV dysfunction, accurately assessing the severity of the valve involvement, or recognizing early cardiac symptoms often make it difficult to determine the optimal timing of mitral valve surgery. ${ }^{3}$ On the other hand, the management of asymptomatic patients with severe MR remains controversial.

Left ventricle ejection fraction (EF) is an important determinant in mitral valve surgery in patients with mitral regurgitation, but in some instances it is difficult to properly measure EF because of abnormally shaped ventricles or poorly defined endocardium. ${ }^{4}$ Despite the ability to identify changes in global LV function in MR, none have been able to identify subclinical LV dysfunction. ${ }^{5,6}$

Tissue Doppler imaging (TDI), strain and strain rate (SR) echocardiography are emerging real time ultrasound techniques that provide a measure of wall motion. They offer an objective means to quantify global and regional left or right ventricular function and to improve the accuracy and reproducibility of conventional echocardiography studies. ${ }^{7} \mathrm{~A}$ number of studies also suggest that SR imaging may also be able to detect subclinical LV dysfunction in a variety of diseases before the development of abnormalities in conventional measures of LV performance, such as ejection fraction. ${ }^{2}$

Recently, it was reported in several studies that, subclinical LV dysfunction was demonstrated via that imaging methods in patients having MR and normal LV function with traditional echocardiography. ${ }^{2,5,6}$ But in these studies, commonly, particular segments of LV were evaluated. However, in this study, we evaluated all of the LV segments globally. In addition, natriuretic peptide levels as a new biochemical marker provides an additional method for assessing the severity and symptoms of MR when the LV EF is normal. ${ }^{8}$ In the literature it has been demonstrated relationship between the severity and symptoms of MR and plasma natriuretic peptide levels. ${ }^{1,8}$ But systolic S/SR and brain natriuretic peptide (BNP) levels together have not been studied previously in MR patients.
The aim of this study was to investigate the subclinical LV dysfunction evaluated by S/SR analysis and plasma levels of BNP in patients with isolated MR.

\section{MATERIALS AND METHODS}

Study design: A cross-sectional observational trial was performed.

\section{Study population}

Thirty-one patients (15 men) referred for echocardiography, who had isolated and organic moderate to severe mitral regurgitation were included. As a control group, 25 healthy (12 male) aged-matched subjects were enrolled to the study. All patients were asymptomatic or minimally symptomatic and the echocardiographic examination was requested on the basis of the presence of a systolic murmur. MR was originated from degeneration, mitral valve prolapse or chronic rheumatic disease. Patients were excluded if they had MR due to ischemic heart disease or cardiomyopathy, had associated mitral stenosis or any other form of valve disease, history of coronary artery disease, cordal rupture associated coronary artery disease, atrial fibrillation and arterial hypertension. Patients with suspicion of coronary artery disease had undergone exercise electrocardiography or angiography.

The study protocol was approved by the local Medical Ethics Committee and all participants gave informed consent.

\section{Study protocol}

All patients underwent a complete cardiac examination by a cardiologist. All individuals underwent standard echocardiographic and Doppler examinations.

Study variables: baseline variables, predictor variable- mitral regurgitation, primary outcome variables- SR and S, secondary outcome variable-BNP

\section{Echocardiography}

All individuals underwent standard echocardiographic and Doppler examinations using Vivid 7 (GE Vingmed Ultrasound, Horten, Norway). Conventional LV M-mode measurements included the estimation of left ventricular end-diastolic dimension, left ventricular end-systolic dimension, thickness of interventricular septum and LV ejection fraction. LV end-systolic and end-diastolic dimensions, the LV ejection fraction and LA dimensions were measured according to the guidelines of the American Society 
of Echocardiography (9). Mitral regurgitation was graded as moderate if the valve ERO was $0.20-0.39$ $\mathrm{cm} 2$ and regurgitant volume was $30-59 \mathrm{~mL}$, severe mitral regurgitation if it was $>0.4 \mathrm{~cm} 2$ and mitral regurgitant volume $>60 \mathrm{~mL}$ (10).

\section{Doppler examination}

LV filling was assessed by measuring inflow at the tips of the leaflets of the mitral valve using pulsed Doppler. The following Doppler-derived parameters were measured: early diastolic peak flow velocity $(E)$, late diastolic velocity $(A)$, and deceleration time of early filling (DT). Isovolumic relaxation time (IVRT) was measured from the cessation of left ventricular outflow to the onset of left ventricular inflow.

\section{Tissue Doppler Imaging}

Myocardial velocities were recorded using a standard PW Doppler technique. Peak systolic velocity (Sm) measured from septal and lateral annulus.

Longitudinal 2D strain and strain rate analysis: First, the LV walls were visualized parallel to the transducer in 2-dimentional imaging and the tissue velocity imaging (TVI) function frame rate was considered $>100 / \mathrm{s}$. Images were obtained with the minimum possible angle and maximum frame rate, only including the LV walls. Images including three consecutive sinus beats at end of the expiratory stage were digitally recorded. Three stable cardiac cycles were stored for each view and cineloop formats were recorded on the hard disk of the echocardiography device. All data were analyzed offline using a dedicated workstation (GE Echopac). Peak systolic $\mathrm{SR}$ and $\mathrm{S}$ during the ejection period were assessed for each segment analyzed. The myocardium of the apical views was divided in two segments (4-chamber; septal, lateral, 2-chamber; inferior, anterior). Both longitudinal $S$ and SR were measured from the basal, middle and apical segments of all walls. Measurements were performed just below the endocardium, by leaving a $10 \mathrm{~mm}$ distance between the two points. For each participant, either in patient or control groups, 12 segments were analyzed. Strain was defined as the instantaneous local trace shortening or lengthening and SR as the rate of shortening or lengthening. Poor quality images and segments with an angular difference $>30$ degrees were excluded from the study. MR grade was assessed by an independent cardiologist blinded to the patient's BNP results. Intraobserver variability was tested with Kappa analysis. The intraobserver coefficient of variation was $<5 \%$.

\section{Measurement of BNP}

Blood sampling was obtained for all patients immediately after enrollment in the echocardiographic laboratory. Samples were immediately placed on ice and transferred to the laboratory facilities. The AxSYM (Abbott Laboratories, Abbott Park IL) analyzer was used for BNP assay, a microparticle enzyme immunoassay, is a 2-site assay that uses a monoclonal anti-BNP antibody and measures a fluorescence product.

\section{Statistical analysis}

All continuous variables were tested for skewness. The continuous parameters were presented as mean \pm standard deviation. Comparisons of demographic, clinical and laboratory characteristics of the patients were performed using one way ANOVA test for continuous variables. Scheffe test was used for post hoc analysis. Kruskal Wallis test was used to compare abnormally distributed data. Categoric variables were compared with the chi-square test. Statistical analyses were carried out using SPSS 13.0 for Windows and a p-value $<0.05$ was considered significant.

\section{RESULTS}

Clinical and echocardiographic features of the patients and the control group were summarized in Table 1 and 2. In patients with severe MR, IVRT was higher to compare with the patients of control group or moderate MR. E wave velocity and a wave velocity were greatest in patients with severe MR when compared with the values of patients with moderate MR and controls. Sm velocities were similar in all groups ( $p>0.05)$.

Longitudinal peak systolic SR values were significantly lower in the severe MR group, when compared with the controls and patients with moderate MR. Similarly, longitudinal peak systolic $S$ values were significantly lower in the severe MR. When compared with the control group, strain and strain rates were also significantly impaired in the inferior, septum, anterior and lateral walls in MR patients (Table 3). S/SR values from segments of all walls of left ventricle were decreased in MR patients (Table 4). Plasma BNP values were significantly higher in severe and moderate MR group when compared with the control subjects (Control group 36.8 \pm 9.2 , moderate MY $81.1 \pm 15.4$, severe MY $107.9 \pm 28$ ) (Table 2). 


\begin{tabular}{lcccc}
\hline & Control $(n=25)$ & Moderate MR $(n=14)$ & Severe MR $(n=17)$ & $p$ \\
\hline Age & $40 \pm 11$ & $39 \pm 12$ & $44 \pm 17$ & 0.684 \\
Heart rate & $76 \pm 13$ & $73 \pm 14$ & $76 \pm 14$ & 0.831 \\
Male n, (\%) & $12(48)$ & $6(43)$ & $9(53)$ & 0.517 \\
Mitral valve & & & \\
Normal (\%) & $25(100)$ & $0^{* * *}$ & $5(29)^{* * *}$ & \\
Fibrotic & 0 & $9(62)^{* * *}$ & $10(59)^{* * *}$ & $<0.001$ \\
Mixematous & 0 & $7(50)^{* * *}$ & $6(35)^{* * *}$ & \\
MVP (\%) & 0 & $3(21)^{* * *}$ & $9(53)^{* * *}$ & \\
Cordal rupture (\%) & 0 & $0(0.0)^{* * *}$ &
\end{tabular}

Table 1. Baseline characteristics of patients with Mitral Regurgitation and Control Groups

MPV: Mitral valve prolapsus, MR: mitral regurgitation

* $p<0.05$ versus control, ${ }^{* *} p<0.01$ versus control, $\quad * * * \quad p<0.001$ versus control

\begin{tabular}{lcccc}
\hline & Control & Moderate MR & Severe MR & $p$ \\
\hline BNP $(\mathrm{pg} / \mathrm{mL})$ & $36,8 \pm 9,2$ & $81,1 \pm 15,4^{* *}$ & $107,9 \pm 28^{* * *}$ & $<0.001$ \\
$\operatorname{LVEF}(\mathrm{mm})$ & $64 \pm 4$ & $61 \pm 5$ & $62 \pm 4$ & 0.45 \\
$\operatorname{LVEDD}(\mathrm{mm})$ & $44 \pm 5$ & $51 \pm 5^{* * *}$ & $57 \pm 4^{* * *}$ & $<0.001$ \\
$\operatorname{LVESD}(\mathrm{mm})$ & $29 \pm 5$ & $34 \pm 5^{* *}$ & $37 \pm 4^{* * *}$ & 0.001 \\
$\operatorname{LAD}(\mathrm{mm})$ & $34 \pm 4$ & $46 \pm 4^{* * *}$ & $55 \pm 7^{* * *}$ & $<0.0011$ \\
$\operatorname{IVS}(\mathrm{mm})$ & $9 \pm 1$ & $10 \pm 1$ & $11 \pm 2^{* *}$ & 0.023 \\
ERO $\left.(\mathrm{cm})^{2}\right)$ & 0 & $0,3 \pm 0,1^{* * *}$ & $0,6 \pm 0,2^{* * *}$ & $<0.001$ \\
RV $(\mathrm{ml})$ & 0 & $45 \pm 13^{* * *}$ & $84 \pm 25^{* * *}$ & $<0.001$ \\
\hline
\end{tabular}

\begin{tabular}{lcccc}
\hline & Control & Moderate MR & Severe MR & $\mathrm{p}$ \\
\hline Mitral E wave & $0,9 \pm 0,2$ & $0,9 \pm 0,2$ & $1,4 \pm 0,5^{* * *}$ & $<0.001$ \\
Mitral A wave & $0,6 \pm 0,1$ & $0,7 \pm 0,2$ & $0,9 \pm 0,3^{* *}$ & 0.01 \\
DT & $197 \pm 55$ & $229 \pm 65^{*}$ & $232 \pm 45^{*}$ & 0.04 \\
IVRT & $82 \pm 12$ & $98 \pm 12^{*}$ & $103 \pm 16^{*}$ & 0.03 \\
Lateral Sm & $8 \pm 2$ & $9 \pm 2$ & $10 \pm 2$ & 0.65 \\
Septal Sm & $7 \pm 2$ & $9 \pm 1$ & $9 \pm 2$ & 0.754 \\
\hline
\end{tabular}

\begin{tabular}{lcccc}
\hline & Control & Moderate MR & Severe MR & $p^{*}$ \\
\hline Lateral S (\%) & $-18,8 \pm 2,3$ & $-16,4 \pm 1,9^{* *}$ & $-13,8 \pm 2,0^{* * *}$ & $<0.001$ \\
Septum S (\%) & $-21,9 \pm 3,0$ & $-17,4 \pm 3,3^{* *}$ & $-15,2 \pm 1,2^{* * *}$ & $<0.001$ \\
Anterior S (\%) & $-19,9 \pm 2,4$ & $-16 \pm 1,5^{* *}$ & $-14,1 \pm 1,7^{* * *}$ & $<0.001$ \\
Inferior S (\%) & $-21,9 \pm 3$ & $-16,7 \pm 2^{* * *}$ & $-13,5 \pm 2,4^{* *}$ & 0.002 \\
Lateral SR ( s-1) & $-1,6 \pm 0,2$ & $-1,3 \pm 0,2^{* *}$ & $-1,0 \pm 0,1^{* * *}$ & $<0.001$ \\
Septum SR (s-1) & $-1,5 \pm 0,2$ & $-1,2 \pm 0,1^{* *}$ & $-0,9 \pm 0,1^{* * *}$ & $<0.001$ \\
Anterior SR ( s-1) & $-1,4 \pm 0,2$ & $-1,1 \pm 0,1^{* *}$ & $-0,9 \pm 0,1^{* * *}$ & $<0.001$ \\
Inferior SR ( s-1) & $-1,5 \pm 0,2$ & $-1,2 \pm 0,2^{* *}$ & $-1,0 \pm 0,1^{* * *}$ & $<0.001$ \\
\hline
\end{tabular}

Table 2. Comparison of brain natriuretic peptide (BNP) and conventional echocardiographic variables of the study groups.

* $p<0.05$ versus control, ${ }^{* *} p<0.01$ versus control, ${ }^{* *} p<0.001$ versus control MR: mitral regurgitation

Data are presented as mean $( \pm)$ standard deviation,

Table 3. Comparison of Doppler and Tissue Doppler values of the study groups

${ }^{*} p<0.05$ versus control, ${ }^{* *} p<0.01$ versus control, ${ }^{* * *} p<0.001$ versus control MR: mitral regurgitation, $A$ : late diastolic transmitral flow velocity, DT: deceleration time, E: early diastolic transmitral flow velocity, IVRT: isovolumic relaxation time, Sm: peak systolic velocity,

Table 4. Comparison of strain (S) and strain rate (SR) levels in patients and control subjects

Data are presented as mean ( \pm ) standard deviation, *Student's t-test, MR: mitral regurgitation,

* $p<0.05$ versus control, ** $p<0.01$ versus control, ${ }^{* * *} p<0.001$ versus control 


\section{DISCUSSION}

The present study showed that BNP levels were elevated in patients with organic moderate or severe MR. S/SR values decreased significantly in patients with moderate to severe MR.

According to the ACC/AHA guidelines, asymptomatic MR patients with an ESD $\geq 4.5 \mathrm{~cm}$ and an $E F \leq 60 \%$ benefit from valve surgery to protect ventricular function. However, if ESD $\geq 4.5 \mathrm{~cm}$ and $E F \leq$ $60 \%$ are used as a cut-off point, there is still a high incidence of heart failure and poor survival after surgery. ${ }^{5,9}$ Thus, the measurements of ESD and EF are not optimal for the evaluation of subclinical ventricular dysfunction in asymptomatic patients. However, difficulties in detecting early LV dysfunction, accurately assessing the severity of valve involvement and the optimal timing of surgery in patients with asymptomatic severe MR remains a challenge. ${ }^{2,5}$

Previous studies have shown that $S$ increases as SV increases and that deformation rate (SR) parallels change in contractility. ${ }^{11}$ But Marciniak et al ${ }^{5}$ subsequently demonstrated that $S / S R$ values decreased with the severity of MR. Their study population consisted of 77 individuals (control $n=23$, mild MR $n=10$, moderate $n=14$ and severe MR $n=$ $30)$. They found that longitudinal peak systolic SR values and peak systolic $S$ values were significantly lower in the severe MR group compared to the control cases and mild/moderate MR patients. But no significant association was seen between severe MR group and moderate MR group. In our study, the decreased S/SR values were observed in patients with MR compared to the control cases.

In another study, SR was significantly greater in patients with contractile reserve compared to the subjects who had no contractile reserve. However SR was not significantly different in contractile (-) patients compared with normal controls. ${ }^{12} \mathrm{~A}$ number of studies also suggest that SR imaging may detect subclinical LV dysfunction in a variety of diseases before LV systolic function was established. ${ }^{13,14}$

Yurdakul et al ${ }^{15}$ demonstrated that S/SR values of MR severity were decreased. Their study population consisted of 54 patients with isolated non-ischemic MR and 30 healthy aged matched subjects were examined (mild MR $n=7$, moderate $n=29$ and severe MR $n=18$ ). They found that longitudinal peak systolic SR values and peak systolic $S$ values were significantly lower in the severe MR group compared to the other groups, which was concordant with our results.

In another study, Detaint et. al ${ }^{1}$ measured BNP levels in 78 patients with MR. Patients with organic and functional MR had higher BNP values compared with control subjects, but the BNP levels were higher in patients with functional MR than those with organic MR. However, mean BNP value in functional MR was higher than the other groups (control and organic MR). In our cohort, plasma BNP values were significantly higher in severe MR group when compared with the control subjects and patients with moderate MR.

Chronic MR can ultimately lead to irreversible changes in the myocardium via progressive LV remodelling, with increasing wall stresses due to dilatation, decrease afterload, increase preload and changes in LV geometry. Measurement of natriuretic peptides and S/SR may be especially useful in the follow-up of asymptomatic patients. When echocardiographic assessment is technically difficult, low BNP levels would suggest that MR is not severe. These observations suggest that BNP levels provide an additional method for assessing the severity of MR when the LVEF is normal.

Conflicting results in previously reported studies might be explained at least in part by different patient selections (such as age, ethnicity, sample size, inclusion of patients with comorbidity) and different diagnostic methods or criteria.

In patients with isolated organic MR, S/SR were found to relate with plasma BNP levels, and thus may be considered as a new echocardiographic parameter for the assessment of global ventricular function during patient follow up. Systolic S/SR and BNP levels together have not been studied previously in MR patients. S/SR imaging may also be used as a risk stratification tool in diagnosing changes in LV dysfunction at a subclinic level in patients with severe asymptomatic MR.

Our study population was relatively small. In normal subjects, natriuretic peptides increased with age and as with flow Doppler, TDI velocity, strain rate and strain measurements are user dependent. Post-operative S/SR values were not recorded which would give more accurate predictability of strain method in the subclinical phase.

In conclusion, we think that S/SR combined with BNP measurement may be helpful in detection of subclinical impairments in left ventricle functions. These interrelations need to be clarified with further studies.

\section{REFERENCES}

1. Singh JP, Evans JC, Levy D, et al. Prevalence and clinical determinants of mitral, tricuspid, and aortic regur- 
gitation (the Framingham Heart Study). Am J Cardiol 1999;83(7):897-902.

2. Lee R, Marwick TH. Assessment of subclinical left ventricular dysfunction in asymptomatic mitral regurgitation. Eur J Echocardiogr 2007;8(1): 175 -84.

3. Pelerin D, Sharma R, Elliott P, Veyrat C. Tissue Doppler, strain, and strain rate echocardiography for the assessment of left and right systolic ventricular function. Heart 2003; Suppl 3: 9-17.

4. Sayar N, Lütfullah Orhan A, Cakmak N, et al. Correlation of the myocardial performance index with plasma B-type natriuretic peptide levels in patients with mitral regurgitation. Int J Cardiovasc Imaging 2008;24(1): 151-7.

5. Marciniak A, Claus P, Sutherland GR, et al. Changes in systolic left ventricular function in isolated mitral regurgitation. A strain rate imaging study. Eur Heart J 2007; 28(21):2627-36.

6. Kim MS, Kim YJ, Kim HK, et al. Evaluation of left ventricular short- and long-axis function in severe mitral regurgitation using 2-dimensional strain echocardiography. Am Heart J 2009;157(2):345-51.

7. Dagdelen S, Yuce M, Ergelen M, Pala S, Kirma C. Quantitation of papillary muscle function with tissue and strain Doppler echocardiography measures papillary muscle contractile functions. Echocardiography 2003; 20(1): 137- 44.

8. Sutton TM, Stewart RA, Gerber IL, et al. Plasma natriuretic peptide levels increase with symptoms and severity of mitral regurgitation. J Am Coll Cardiol 2003: 18;41(18): 2280-7.

9. Bonow RO, Carabello BA, Kanu C, et al. Guidelines for the Management of Patients With Valvular Heart
Disease:A Report of the American Heart Association Task Force on Practice guidelines. Circulation 2006;114(3):450-527.

10. Leopoldo P, Alberto dA, Jose Luis Rodrigo JL, et al. Chronic Mitral Regurgitation: A Pilot Study to Assess Preoperative Left Ventricular Contractile Function Using Speckle-Tracking Echocardiography. J Am Soc Echocardiogr 2009; 22(6): 831-8.

11. Weidemann F, Jamal F, Sutherland GR, et al. Myocardial function defined by strain rate and strain during alterations in inotropic states and heart rate. Am J Physiol Heart Circ Physiol 2002; 283(6): 792-9.

12. Lee R, Hanekom L, Marwick TH, Leano R, Wahi $\mathrm{S}$. Prediction of subclinical left ventricular dysfunction with strain rate imaging in patients with asymptomatic severe mitral regurgitation. Am J Cardiol 2004;15;94(10):1333-7.

13. Koyama J, Ray-Sequin PA, Falk RH. Longitudinal myocardial function assessed by tissue velocity, strain and strain rate tissue Doppler echocardiography in patients with $\mathrm{AL}$ (primary) cardiac amyloidosis. Circulation 2003;107(16):2446 -52.

14. Palka $P$, Lange $A$, Fleming $A D$, et al. Differences in myocardial velocity gradient measured throughout the cardiac cycle in patients with hypertrophic cardiomyopathy, athletes and patients with left ventricular hypertrophy due to hypertension. J Am Coll Cardiol 1997;30(6):760-8.

15. Yurdakul S, Tayyareci Y, Yildirimturk O, Memic K, Aytekin V, Aytekin S. Subclinical left ventricular dysfunction in asymptomatic chronic mitral regurgitation patients with normal ejection fraction: a combined tissue Doppler and velocity vector imaging-based study. Echocardiography 2011;28(8):877-85. 